\title{
The Quest for a Small Animal Model for HIV Infection and Disease
}

\author{
Jorge C.G. Blanco ${ }^{1}$, Lioubov M. Pletneva ${ }^{1}$, \\ Lorraine E. Earle ${ }^{2}$ and William I. Frels ${ }^{2}$ \\ ${ }^{1}$ Sigmovir Biosystems Inc. \\ ${ }^{2}$ Virion Systems Inc., Rockville, Maryland

\section{Introduction}

Development of a small animal model to study human immunodeficiency virus type-1 (HIV-1) infection began with the discovery of the disease itself. Such a model would significantly facilitate studies of disease pathogenesis, vaccine and anti-viral drug development and testing. However, HIV-1 replication is subject to a number of speciesspecific restrictions at the level of cellular entry and/or post-entry. Although many attempts to develop a model that can overcome these cellular restrictions have been attempted, no satisfactory small animal model for HIV-1 infection has been identified to date.

The cotton rat has been a superb model for human infectious diseases. This "new world" wild rodent, that is now highly inbred, was shown to be susceptible to an extraordinary spectrum of human pathogens, particularly viruses. Importantly, it was shown by two different laboratories that cotton rats can be infected with the Human Immunodeficiency Virus (HIV-1), and that virus can be detected long after infection and antibodies are generated against viral proteins. In more recent studies, cotton rat cells were made permissive to HIV infection by engineering the expression of human co-receptors for HIV-1, supporting HIV-1 infection, DNA integration, and more importantly, production of infective HIV particles.

Importantly, the cotton rat is susceptible to other two pathogens that are extraordinarily associated with HIV-AIDS, Mycobacterium tuberculosis (TB) and herpes simplex virus (HSV). We will review previous attempts to develop a small animal model for HIV infection and explore the scientific and commercial significance of developing such a model. We will describe the cotton rat model of HIV, TB, HSV as they stand today. Finally, we will describe recent advances in the production of transgenic cotton rats that express HIV receptor molecules.

\section{Animal models for HIV-1}

The total number of Human Immunodeficiency Virus (HIV)-infected people worldwide is estimated at 40 million (and 600 new infections per hour). Preventive vaccine and prophylactic therapies against HIV infection and more efficient drugs for AIDS are not only urgently needed, but also, scientifically possible. However, one of the major obstacles in 
translational HIV research rests in the absence of inexpensive and efficient pre-clinical trial models.

Several animal models for HIV-1 infection have been useful, adding complementary information for specific aspects of HIV-1 disease in humans. Limitations of the current models include the limited availability and high cost (non-human primates), absence of or delay in an acquired immunodeficiency syndrome (AIDS), lack of viremia, and permissiveness only to related retroviruses. These models include human HIV-1 in chimpanzees, macaques, mice, rats, rabbits, and Simian HIV in several species of monkeys (Cohen, 2001; Nath, Schumann, and Boyer, 2000; van Maanen and Sutton, 2003).

HIV-1 replication is subject to a series of species-specific restrictions in cells of non-primate species. Binding of HIV-1 envelope protein $(E n v)$ to both CD4 and the appropriate member of the seven-transmembrane G-protein-coupled receptor superfamily are necessary for efficient entry of HIV-1 (Berger, Murphy, and Farber, 1999; Deng et al., 1996). Several different chemokine receptors (CCR2b, CCR3, CCR5, or CXCR4) or orphan chemokine receptor-like molecules (STRL33, GPR1, GPR15, V28, APJ) may participate in HIV-1 entry, but hCXCR4 and hCCR5 are the principal co-receptors for X4 (T-cell line-tropic) or R5 (macrophage-tropic) isolates, respectively. Blocking and down-regulation of these two cytokine receptors are ways by which their physiological ligands or modified analogues can reduce HIV-1 entry (Stantchev and Broder, 2001).

One approach for developing animal models in laboratory rodents has been to identify and then overcome specie-specific barriers that HIV encounters during its replication. The ultimate goal is to use the knowledge to develop an immunocompetent transgenic small animal model that is fully permissive to HIV replication. The barriers that stall replication in mouse and rat cells have been studied. Mice that express hCD4 and hCCR5 or hCXCR4 were first developed (Browning et al., 1997; Sawada et al., 1998). Preliminary results with these mice were initially exciting because the expression of the transgenes promoted viral entry, but were ultimately disappointing because the mice did not support viral replication (Browning et al., 1997). These results were partly explained by differences between the human and the mouse cyclin T1 (CycT1), which is an important cellular component of the p$\mathrm{TEFb}$ transcription factor complex that is responsible for transcription from the viral long terminal repeat (HIV-LTR) (Garber et al., 1998; Wei et al., 1998). Recent studies indicate additional restrictions in mouse cells. Transgenic mice expressing human cyclin T1, human CD4, and the human chemokine receptor failed to produce high levels of HIV (Garber et al., 1998; Mariani et al., 2001) and other downstream elements like the maturation of the gag protein to produce p24 were also shown to be compromised in mouse cells (Mariani et al., 2001). These post-transcriptional defects result in a dramatically reduced yield of infectious virus (up to 10,000-fold) in a single cycle of HIV replication, as compared to human cells (Bieniasz and Cullen, 2000).

In 2001, Goldsmith and co-workers made improvements in the rat model for HIV. They first demonstrated that rat cells are more efficient for replication of HIV than mouse cells (Keppler et al., 2001), producing substantial levels of viral p24gag. Based on these results, they engineered rats transgenic for the hCD4 and the hCCR5 that expressed the genes in CD4+ T lymphocytes, macrophages, and microglia (Keppler et al., 2002). They found that these cells could be productively infected by various recombinant and primary R5 strains of HIV-1 ex vivo, although the animals do not support viremia during infection. 
The laboratory rabbit appears to be susceptible to HIV, but requires large inocula and viral replication does not spread (Dunn et al., 1995; Filice, Cereda, and Varnier, 1988). Rabbit cell lines expressing hCD4 and hCCR5 demonstrated an increase in infection and replication of CCR5 dependent strain of HIV (JR-CSF and YU-2)(Speck et al., 1998). Recently, new studies support the previous evidence for the susceptibility of rabbit cells, especially T cells, to HIV infection and suggest that in addition to the receptor complex transgenesis, modifications in gag and possibly vif of the HIV-1 might render the rabbit model fully permissive to infection by HIV-1 (Tervo and Keppler, 2010).

Recently, a small animal model of HIV transmission was developed by transplanting human bone marrow, liver, and thymus (BLT) into severe combined immunodeficient mice (Melkus et al., 2006). Consequently, human APCs and lymphocytes populate the mucosal surfaces, and the model can be used to assess some strategies to prevent vaginal HIV transmission (Denton et al., 2008). Further, once infected, the BLT mice generate humoral and cellular HIV-specific immune responses (Brainard et al., 2009). Some of these models allow transmission of HIV via the vaginal and rectal mucosa and display high-level viremia and CD4 $\mathrm{T}$ cell depletion. Unfortunately, these models are technically challenging, timeconsuming, and not amenable to widespread use. Moreover, HIV-1 infected, xenotransplant mice mount low or dysfunctional adaptive immune responses to HIV infection, limiting these studies of natural immune control and vaccine testing.

\section{The cotton rat}

The cotton rat is a common New World rodent ranging in distribution from the southern United States through Mexico, Central America, Colombia and Venezuela. Eight species are recognized, with a karyotype ranging from 22 to 52 chromosomes. The most recent classification is to the Subfamily Sigmodentinae of the family Cricetidae, which includes New World mice, rats, voles, lemmings and muskrat. Sigmodon hispidus is the most commonly used cotton rat in biomedical research, but some investigators have also utilized laboratorybred S. fulviventer (Piazza et al., 1992; Porter et al., 1991).

In the 1930's, it was discovered that inoculation of the cotton rat with poliovirus induced a paralytic disease, while other laboratory rodents did not develop disease (Armstrong, 1939). For over a decade, $S$. hispidus remained the prime animal model for polio until supplanted by monkeys and mice, with mice requiring extensive adaptation of virus. Since then, the cotton rat has been extensively used as a model to study different aspects of infection by respiratory syncytial virus (Li et al., 2000; Malley et al., 1998; Prince et al., 2001; Prince et al., 1978; Prince et al., 1999; Rodriguez et al., 1997; Tang et al., 2001), influenza A and B (Sadowski et al., 1987), parainfluenza viruses types 1, 2, and 3 (Ottolini et al., 2000; Porter et al., 1991; Prince et al., 2001; Sadowski et al., 1987), herpes simplex virus type 1 (HSV-1) (Lewandowski et al., 2002), HSV-2 (Yim et al., 2005), measles virus (Niewiesk, 2001; Niewiesk et al., 1997; Wyde et al., 1999), as well as several serotypes of adenovirus (Brunori et al., 2001; Ginsberg et al., 1989; Ginsberg, Moldawer, and Prince, 1999; Rojas-Martinez et al., 1998; Tsubota et al., 1998; Wildner and Morris, 2002). Finally, cotton rats are also natural reservoirs of several viruses of importance as emerging human pathogens. These include Venezuelan equine encephalitis (Wang et al., 2001), Guaranito and Pirital viruses (Fulhorst et al., 1999); and several species of hantavirus (Fulhorst et al., 1997; Glass et al., 1998; Hutchinson, Rollin, and Peters, 1998; Mantooth et al., 2001). 
S. hispidus and S. fulviventer are fully inbred and both species are available from the Sigmovir Biosystems Inc. colony, a USDA licensed dealer for cotton rats.

\section{HIV infection in cotton rat}

Infection by HIV is defined as the replication of detectable virus in the host and the development of antibodies against HIV-1 proteins. Previously, one laboratory in the U.S. (Langley, Prince, and Ginsberg, 1998) and another in Russia (Rytik et al., 1995; Rytik et al., 2004) demonstrated that HIV-1 was detected in tissues of cotton rats previously infected with HIV-1. In the U.S. study (Langley, Prince, and Ginsberg, 1998), cotton rats were infected with HIV-1 and proviral DNA was detected in peripheral blood mononuclear cells (PBMCs) and tissues including spleen, thymus, and bone marrow from infected animals. Virus stimulated a strong, specific, and long-lasting immune response (in some animals included neutralizing antibodies and antibodies recognizing major HIV antigens) that was maintained up to 1 year post-infection. Although not demonstrable by direct culture of PBMCs or tissues from infected animals, infectious virus replicated at a low level in PBMCs of these animal because its presence was detected in animals that received three serial passages of blood from the original infected cotton rats.

In addition, Rytik and collaborators have also described the permissiveness of the cotton rat to HIV-1 infection by detection of viral DNA in spleen and brain $(100 \%$ of the animals after 6 month), increase in mortality $(17 \%)$, and morphological changes in cells of the central nervous system (CNS). These data strongly indicate that non-transgenic cotton rats are semipermissive to HIV-1 replication. These findings imply that a productive infection may occur in cotton rats. The cotton rat offers several advantages for the development of an animal model, including small size, convenience of breeding, and the increasing availability of reagents to study the immunological and pathological aspects of HIV-1 disease (R\&D Systems Inc).

\subsection{Cotton rat primary macrophages support HIV-1 gene expression}

Recently, the ability of cotton rat cells to support HIV-1 transcription was assessed by our laboratory using macrophages from two different cotton rat species (S. hispidus and $S$. fulviventer), from BALB/c mice, and from humans. Macrophages were transfected with a luciferase reporter gene encoding pNL4 env-R+, which provides a quantitative marker of HIV-1 gene expression. Macrophages from S. hispidus and S. fulviventer supported transcription of the HIV-1 derived backbone as indicated by enhanced luciferase activity compared with that of cells transfected with the control promotor-less luciferase construct (Fig. 1). The levels of transcription found in cotton rat macrophages were comparable to that measured in human macrophages, and all were significantly greater in comparison to mouse macrophages transfected with the HIV-1 reporter plasmid. Interestingly, the levels of transcription in macrophages of S. hispidus was at least 10 folds higher than the activity recorded in macrophages of humans or $S$. fulviventer. Although the nature of this high transcription efficiency of the LTR in S. hispidus is unknown, it could be related to the lift of a particular blockage or to an increase RNA/protein stability of luciferase. Transfection efficiencies measured by the expression of a CMV promoter-driven $\beta$-galactosidase activity were equivalent in cells of all species. These data indicate that cotton rat macrophages support transcription from the HIV-1-LTR and apparently lack the transcriptional blocks found in mouse cells. 

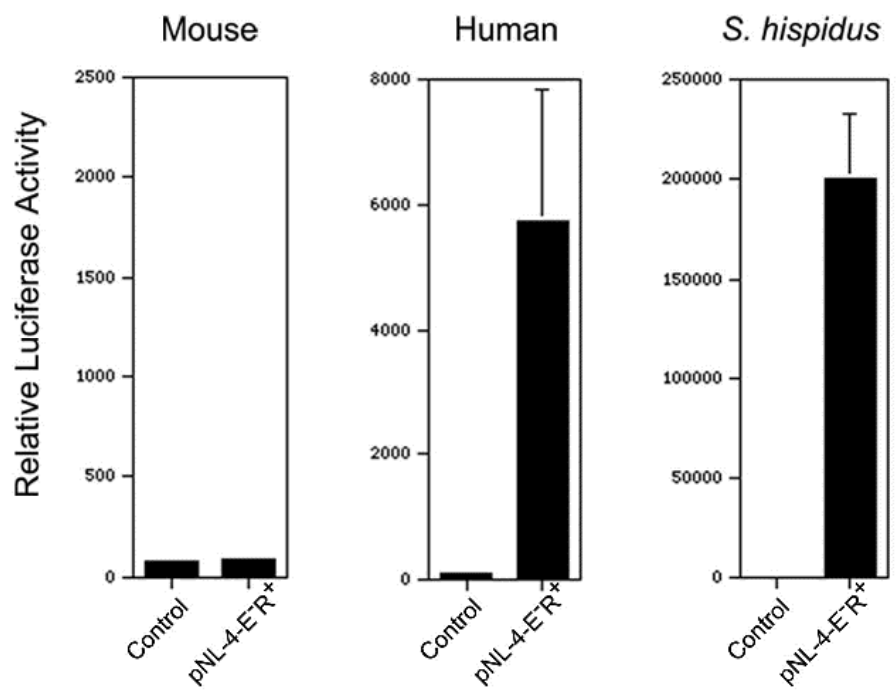

\section{S. fulviventer}

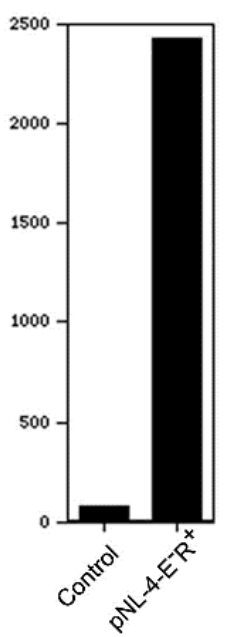

Fig. 1. Macrophages from S. hispidus and S. fulviventer supported transcription of the HIV-1 derived backbone. Mouse, human, S.hispidus and S. fulviventer macrophages were transfected with a control plasmid (pGL3-basic, Promega) or a plasmid containing a HIV-1 NL-4-E- $R^{+}$. Human macrophages were prepared by differentiating elutriated monocytes (from the NIH Blood Bank) for 14 days in high-cell density cultures of D-MEM media supplemented with $10 \%$ human $\mathrm{AB}$ serum, $2 \mathrm{mM}$ L-glutamine and antibiotics in $100 \mathrm{~mm}$ square Petri. Cotton rat peritoneal macrophages from S. hispidus and S. fulviventer were prepared by injecting 3-month-old rats intraperitoneally with $8 \mathrm{ml}$ of thioglycollate broth. Mouse macrophages were obtained in similar fashion injecting $3 \mathrm{ml}$ of thioglycollate broth into the peritoneal cavity of Balb/c mice. Four days post injection, animals were sacrificed by $\mathrm{CO}_{2}$ inhalation and the peritoneal cavity was washed twice with cold saline solution. Cells obtained were seeded in culture plates as indicated for human macrophages. For transfection of human, mouse, and cotton rat macrophages the ratio of transfection reagent in $\mu \mathrm{l}$ (FuGENE 6, Roche Molecular Biochemical) to NL4-3 derived backbone plasmid in $\mu \mathrm{g}$ was 4 to 1 , where the total of $4.5 \mu \mathrm{g}$ of plasmid DNA were used for each $10^{6}$ macrophages. Transfection was carried out overnight at $37^{\circ} \mathrm{C}$ and the next day macrophages were washed and incubated for an additional $48 \mathrm{~h}$ before lysis and quantification of luciferase activity. The results represent luciferase activity obtained from transfected cells in triplicate wells from a representative experiment.

\subsection{Cotton rat cell lines expressing the HIV-1 receptor complex are susceptible to HIV- 1 infection}

Two different cotton rat cells lines, CCRT (an osteosarcoma) and VCRT (an undifferentiated spindle cell sarcoma), that were selected for expression of hCD4/hCXCR4 and hCD4/hCCR5, were tested for infection with three well characterized isolates of HIV-1 virus: the $\mathrm{MN}$ isolate (a T-tropic HIV isolate that infects $\mathrm{T}$ cell lines and peripheral $\mathrm{T}$ cells, but not monocytes, and uses hCXCR4 as co-receptor), and the BAL and US1 isolates (Mtropic HIV isolates that infect monocytes and use hCCR5 as co-receptor). In all cases, the 
levels of p24gag in the supernatant of cotton rat cells expressing the HIV receptor complex were significantly higher than in control, untransfected cell cultures, with a peak of p24gag production evidenced on day 6 post-infection (Blanco et al., 2009). Fully mature, infectious HIV-1 particles were efficiently synthesized and assembled in HIV-1-infected cotton rat cells since PHA-activated PBMCs (pool of human PBMC from negative donors) or H9 cells incubated with the derived supernatants from cotton rat cells produced detectable amounts of p24gag $(\sim 200 \mathrm{pg} / \mathrm{ml})$ as early as day 3 post-transfer of all cotton rat-derived stocks. Furthermore, proviral DNA was detected in infected cotton rat cells, and subsequent direct cloning demonstrated that HIV-1 DNA integrates into the genome of infected cells (Blanco et al., 2009). The sequence of one of the integrated fragments $(\sim 1.6 \mathrm{~kb})$ revealed the presence of $650 \mathrm{bp}$ corresponding to sequence of the 5' LTR of HIV-MN attached to $950 \mathrm{bp}$ of a cotton rat genomic DNA sequence (GenBank acc\# AY703985), and further demonstrates that cotton rat cells are able to support integration of viral DNA in their genome (Blanco et al., 2009).

\section{The cotton rat model of tuberculosis}

HIV fuels the TB epidemic in many ways. HIV promotes progression to active TB in both categories, that is, people with recently acquired TB and those with latent Mycobacterium tuberculosis infection (LTBI). HIV is the most powerful known risk factor for reactivation of LTBI to active disease. HIV also appears to increase the risk of pediatric TB, which is itself difficult to diagnose. A small animal model that is susceptible to infection with both pathogens could lead to development of treatments and vaccines that can target more efficiently this unparalleled problem for the population of third world countries.

The natural history of TB infection in S. hispidus and S. fulviventer has been studied (Elwood et al., 2007). The relatively short life span of the cotton rat (12-18 months) makes it possible to study TB infections throughout the entire life span of the animal. The studies demonstrated that young cotton rats experience a primary tuberculous pulmonary infection characterized by typical granuloma formation. There were differences in response to infection between the two species, with $S$. fulviventer demonstrating greater mortality than $S$. hispidus. Gross inspection of TB-infected cotton rat lungs show whitish nodular lesions and large numbers of TB ( 1 X $\left.10^{5-7} \mathrm{cfu}\right)$ were cultured from granulomas, spleen, and occasionally in smaller numbers from liver and bone marrow. Tuberculous lesions may also be seen in the adrenal glands (other organs remain to be examined) (Elwood et al., 2007). Established granulomas in some cases underwent central necrosis and calcification and cytokine genes are more highly expressed in the granuloma than in the unaffected areas of the lung. A minority of animals, about $20-30 \%$ with primary infection, develop serious progressive TB pulmonary disease, wasting, and succumb to infection. The remaining animals control or clear their infection by two to four months after challenged. Later, about half of these otherwise well appearing animals continue to have small numbers of TB recovered from lungs $\left(1 \times 10^{2-3} \mathrm{cfu}\right)$ despite no microscopic evidence of inflammation or clinical disease. However, $50 \%$ of immunocompetent animals surviving past 9 months demonstrated positive lung tissue cultures for TB without histological evidence of disease. These findings are consistent with the development of LTBI. Furthermore, reactivation of disease occurs in the surviving animals after immunosuppression with cyclophosphamide (Elwood et al., 2009), indicating that a model of HIV-1 infection in the cotton rat more likely will parallel the course of TB disease seen in co-infected individual. 


\section{The cotton rat model of HSV infection}

Genital herpes is one of the most prevalent sexually transmitted diseases (STD) worldwide and is the most common cause of genital ulcers. In the US, $17 \%$ of the population is seropositive for herpes simplex virus type 2 (HSV-2) and 58\% for HSV-1, which is emerging as a major cause of genital herpes infections in developed countries (Roberts, 2005; Roberts, Pfister, and Spear, 2003; Xu et al., 2006). The HSV-2 seroprevalence rates are much higher in some populations, reaching $90-95 \%$ among HIV-infected subjects and female sex workers in developing countries where HSV-2 remains the dominant cause of genital ulcerative disease (Nagot et al., 2007). Implications of genital herpes infection include the risk of transmission to sexual partners and offspring as well as an increased risk of acquiring and transmitting HIV. Epidemiological studies consistently demonstrate that mucosal HIV-1 shedding is more frequent and in greater amounts during mucosal and subclinical reactivations (Corey et al., 2004; Nagot et al., 2007; Watson-Jones et al., 2008). HSV-2 can be detected in swabs obtained from the cervix from seropositive subjects by culture on $3 \%$ of days and by sensitive DNA PCR on about $20 \%$ of days, illustrating the high frequency of asymptomatic shedding (Wald et al., 2000). Being sero-positive for HSV-2 is associated with a 3- to 10-fold increased risk of HIV-1 acquisition in women, based on longitudinal cohort studies showing HSV-2 infection preceding HIV-1 acquisition and adjusted for sexual behavior (Celum et al., 2004; Celum, 2004; Freeman et al., 2006). In sub-Saharan Africa, more than a quarter of incident HIV infections may be attributed directly to HSV-2 (Abu-Raddad et al., 2008). A recently completed Phase IIb study, CAPRISA 004, found that $1 \%$ Tenofovir (TFV) vaginal gel was effective in reducing HIV transmission to high risk, seronegative, sexually active women (Abdool Karim et al., 2010). An unanticipated finding in these trials was that TFV gel provided $51 \%$ protection against HSV-2 (Q. Abdool Karim, unpublished data). Together, these results highlight the importance of the development of a preclinical model for testing combined therapies against HIV and HSV.

Female cotton rats (S. hispidus) are susceptible to genital HSV infection and do not require hormonal treatment to become infected (Yim et al., 2005). After HSV inoculation, animals develop lesions by day 12, without mortality. This contrasts significantly with the murine model, where medroxyprogesterone treatment is required for consistent infection, a higher inoculum is typically required, and mice develop hind limb paralysis and must be euthanized (Parr et al., 1994; Parr and Parr, 2003). In humans, primary genital herpes infections may be associated with constitutional symptoms, aseptic meningitis, and clinically asymptomatic spread of the virus to liver, lungs, and kidneys. In cotton rats, viral DNA was readily detected in vaginal swabs on days 3, 5, and 7 post-infection and could also be detected in the liver, lung, kidney, lumbosacral cord, and brain on the same days. Viral DNA was detected 100 days postinfection in lumbosacral cord, but not the brain, suggesting a state of latency in cotton rat dorsal root ganglia. Following healing of the primary lesions, $15-20 \%$ of female cotton rats display clinical signs of spontaneous reactivation with lesion formation at any given time (Yim et al., 2005). The lesions associated with reactivation are generally smaller than primary lesions, similar to human disease. Spontaneous recurrences are often preceded by virus being detected in vaginal swabs by PCR or culture, again similar to the human situation. Reactivation can be enhanced experimentally by dexamethasone treatment, increasing the rate to two- to three-fold higher than the rate of spontaneous reactivation.

Clinically silent reactivation of HSV is much more common than previously recognized and may play an important role in fueling both the HSV and HIV epidemic. For example, in a 
study of shedding in HSV-2 seropositive subjects who self-collected swabs 4 times daily for 60 days, HSV-2 was detected by PCR on 19\% of days with a median duration of $13 \mathrm{~h}$ (Mark et al., 2008). Intermittent spontaneous viral shedding was observed in the absence of clinical lesions and was also detected by PCR and culture prior to the onset of clinical recurrences (Yim et al., 2005); these findings are consistent with those observed with human HSV infection and set up a potential valuable model of HSV and HIV co-infection and treatment.

\section{Progress toward the development of a cotton rat model of HIV infection}

Mammalian transgenic experiments have contributed tremendously to our understanding of numerous complex biological processes. While other laboratory animals have been used to produce transgenic lines, genetic manipulation has never been attempted in cotton rats. Development of transgenic cotton rat that is permissive to infection with HIV-1 was considered a project of sufficient importance to justify the development of the transgenic technique in this relatively new animal model. Since cotton rat stem cells are not available, pronuclear microinjection of DNA and subsequent embryonic transfer is required. To do that, an entire characterization of the reproductive habits of the cotton rat S. hispidus (52 chromosomes, inbred for more than 70 generations) including understanding the anatomy of its reproductive system, mating, and mothering habits, hormone stimulation, and fertilized egg recovery was required to optimize specific parameters for the production of transgenic cotton rats.

Female cotton rats maintained in 12-hour light-dark cycle (lights off from 6 PM to 6 AM) ovulate approximately every 9 days. Superovulation by hormone injection has been used in mice and rats to increase the number of one-celled fertilized eggs to use for microinjection. This is achieved by a course of treatment with pregnant mare serum gonadotrophin (PMS), followed by human chorionic gonadotrophin (HCG). The optimal age for hormone treatment of female cotton rats was 12 weeks, with the treatment consisting of 30 IU of PMS, followed with the same amount of HCG, 4 days later. Following these pretreatment conditions, matings were successful $65 \%$ of the time (i.e., $65 \%$ of females exhibit a copulatory plug) producing an average of 6 fertilized eggs per female (Fig. 2).

Two hours after coitus, fertilized eggs can be retrieved from the oviduct (Fig. 3A). The shape and size of the cotton rat fertilized eggs resemble those of mice (Fig. 3B) with a distinguishable male and female pronucleus (FIG. 3C). Microinjection is performed using standard procedures by injecting $1 \mathrm{pl}$ of purified and linearized DNA into the male pronucleus (Fig. 3D). Pseudopregnant recipients are used as surrogate mothers to nurture microinjected eggs to birth. These are young female cotton rats that are set for mating with vasectomized males. First, young female cotton rats at the peak of oestrus are identified and placed with vasectomized males at the beginning of the dark cycle. The mating rate of the young females with the vasectomized males is $\sim 30 \%$.

There is a very different anatomy of the cotton rat female reproductive system when compared to the mouse or laboratory rats, e.g., the mouse and the rat have an evident ampulla where the fertilized eggs are located and where the transfer of embryos take place through the infundibulum. However, we could not find any evidence of the existence of an ampulla in the cotton rat. The infundibulum, however, is located inside the bursal sac as in the mouse. In contrast to the mouse that has the infundibulum free and accessible into the bursa to transfer the eggs, the cotton rat infundibulum is associated with the wall of the bursal sac. Eggs are implanted in the part of the oviduct that is proximal to the bursal sac 
(were the ampulla is anatomically located), and where the eggs are located at $20 \mathrm{hr}$ postcoitum in the superovulated females (Fig. 3A).

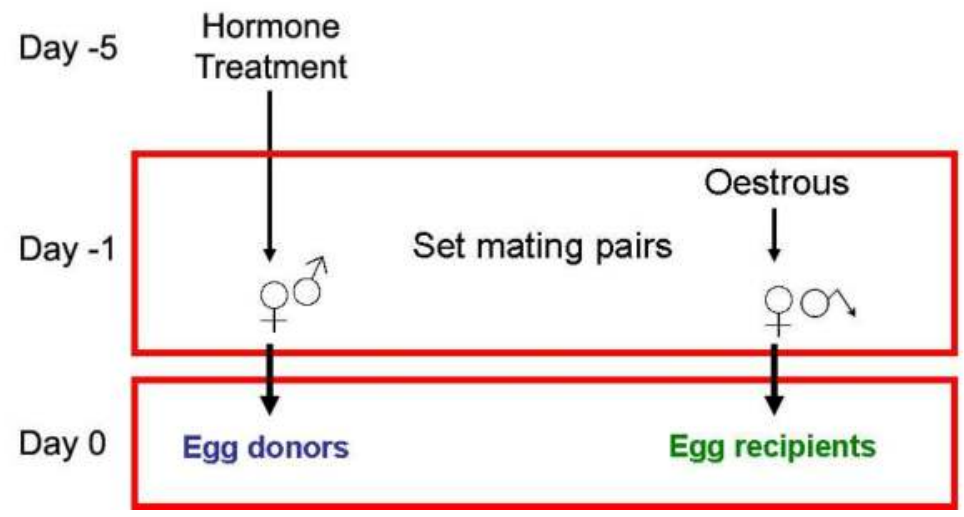

Fig. 2. Schematized protocol for the isolation of cotton rat fertilized eggs (egg donors, left side), and for the preparation of recipient pseudo-pregnant females (egg recipients, right side). Super-ovulation of female cotton rats is achieved by course of treatment of PMS followed by HCG before caging them with males for mating. In addition, female cotton rats in estrous are identified and set in mating pairs with vacectomized males. On day 0 , females that have copulatory plugs are identified; eggs are isolated from oviducts of super-ovulated females, microinjected with DNA, and transferred to oviducts of pseudo-pregnant recipient females.

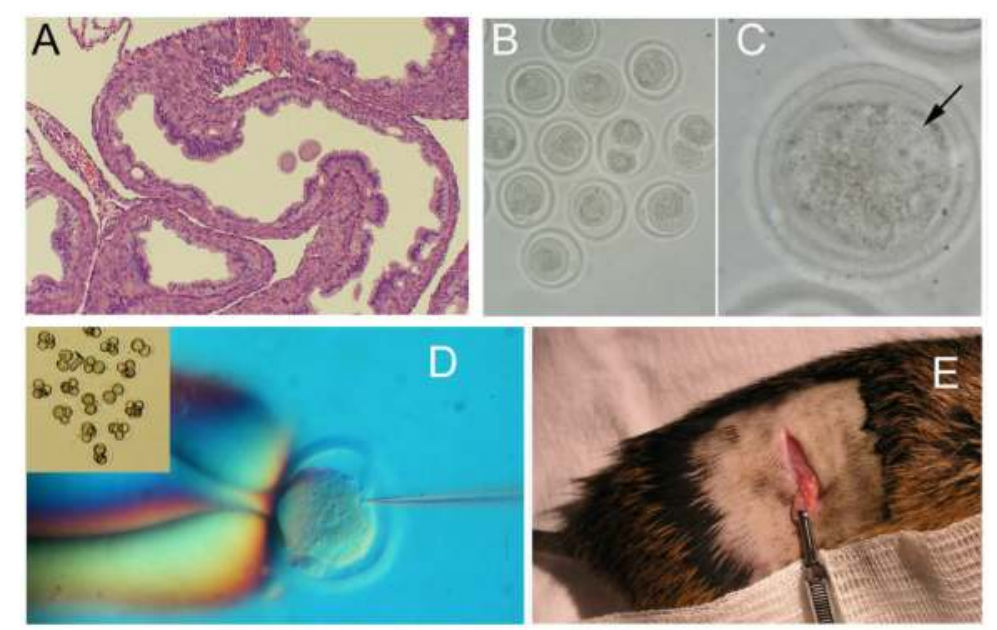

Fig. 3. Development of the transgenic technique in cotton rats. (A) H\&E staining of cotton rat oviduct showing the location of the eggs. (B).Cotton rat fertilized eggs isolated from a super-ovulated cotton rat. (C) Fertilized cotton rat egg in which the male pro-nucleus, where DNA microinjection takes place, is depicted. (D) Microinjection of DNA in a fertilized egg. Insert shows viable eggs in culture after DNA microinjection. (E).Exposure of the oviduct of a pseudopregnant female cotton rat for embryo transfer. 


\section{Generation of transgenic cotton rats}

The original genomic constructs for human CD4, CCR5 and CycT1 that were previously used in the mouse and rats (Keppler et al., 2002; Sawada et al., 1998), and that expressed their products in a tissue-specific manner (kindly provided by Dr. Dan R. Littman, M.D., Ph.D., Director of the Molecular Pathogenesis at Skirball Institute of Biomolecular Medicine) were purified to homogeneity for pronuclear microinjections. In the first set of microinjections and embryo transfer experiments, a set of three founders ( 2 females and one male) were obtained. After crossing, the F1 generation was genotyped for human CD4 and CCR5. Several animals in the F1 generation were positive by PCR and Southern blot genotyping for hCD4 and CCR5, indicating the production of transgenic cotton rats (Fig. 4). None of the animal genotyped were found to be transgenic for both transgenes. We are currently in process of determining expression of these genes in the transgenic cotton rats in order to produce double transgenics and subsequently initiate infection experiments to determine the degree of susceptibility to HIV-1 infection achieved.

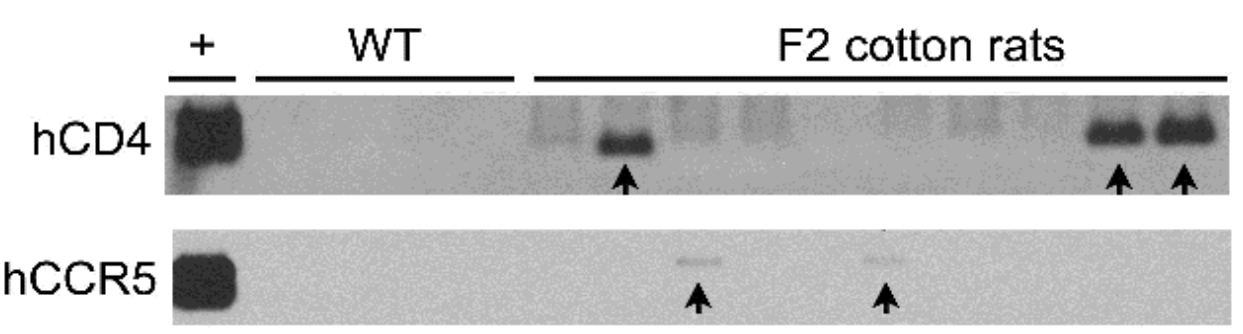

Fig. 4. Genotyping the F2 generation of cotton rats harboring transgenic hCD4 (upper panel) and transgenic hCCR5 (lower panel) by RT-PCR followed by Southern blot. PCR amplifications using DNA from the original transgenic constructs $(+)$, and from wild-type cotton rats (wt) are depicted as controls.

\section{Acknowledgment}

The authors will like to acknowledge Drs Gregory A. Prince, Val Hemming, Vicky Polonis, Christopher Broader, Tsanko Stantchev for participating in this work during the years. Part of this work has been supported by NIH grant R44 AI054297 to JCGB.

\section{References}

Abdool Karim, Q., Abdool Karim, S. S., Frohlich, J. A., Grobler, A. C., Baxter, C., Mansoor, L. E., Kharsany, A. B., Sibeko, S., Mlisana, K. P., Omar, Z., Gengiah, T. N., Maarschalk, S., Arulappan, N., Mlotshwa, M., Morris, L., and Taylor, D. (2010). Effectiveness and safety of tenofovir gel, an antiretroviral microbicide, for the prevention of HIV infection in women. Science 329(5996), 1168-74.

Abu-Raddad, L. J., Magaret, A. S., Celum, C., Wald, A., Longini, I. M., Jr., Self, S. G., and Corey, L. (2008). Genital herpes has played a more important role than any other 
sexually transmitted infection in driving HIV prevalence in Africa. PLoS ONE 3(5), e2230.

Armstrong, C. (1939). The experimental transmission of poliomyelitis to the eastern cotton rat, Sigmodon hispidus jispidus. Public Health Reports, Wash DC 54, 1719-1721.

Berger, E. A., Murphy, P. M., and Farber, J. M. (1999). Chemokine receptors as HIV-1 coreceptors: roles in viral entry, tropism, and disease. Annu Rev Immunol 17, 657700.

Bieniasz, P. D., and Cullen, B. R. (2000). Multiple blocks to human immunodeficiency virus type 1 replication in rodent cells. J Virol 74(21), 9868-77.

Blanco, J. C., Pletneva, L. M., Wieczorek, L., Khetawat, D., Stantchev, T. S., Broder, C. C., Polonis, V. R., and Prince, G. A. (2009). Expression of Human CD4 and chemokine receptors in cotton rat cells confers permissiveness for productive HIV infection. Virol J 6(1), 57.

Brainard, D. M., Seung, E., Frahm, N., Cariappa, A., Bailey, C. C., Hart, W. K., Shin, H. S., Brooks, S. F., Knight, H. L., Eichbaum, Q., Yang, Y. G., Sykes, M., Walker, B. D., Freeman, G. J., Pillai, S., Westmoreland, S. V., Brander, C., Luster, A. D., and Tager, A. M. (2009). Induction of robust cellular and humoral virus-specific adaptive immune responses in human immunodeficiency virus-infected humanized BLT mice. J Virol 83(14), 7305-21.

Browning, J., Horner, J. W., Pettoello-Mantovani, M., Raker, C., Yurasov, S., DePinho, R. A., and Goldstein, H. (1997). Mice transgenic for human CD4 and CCR5 are susceptible to HIV infection. Proc Natl Acad Sci U S A 94(26), 14637-41.

Brunori, M., Malerba, M., Kashiwazaki, H., and Iggo, R. (2001). Replicating adenoviruses that target tumors with constitutive activation of the wnt signaling pathway. J Virol 75(6), 2857-65.

Celum, C., Levine, R., Weaver, M., and Wald, A. (2004). Genital herpes and human immunodeficiency virus: double trouble. Bull World Health Organ 82(6), 447-53.

Celum, C. L. (2004). The interaction between herpes simplex virus and human immunodeficiency virus. Herpes 11 Suppl 1, 36A-45A.

Cohen, J. (2001). Building a small-animal model for AIDS, block by block. Science 293(5532), 1034-6.

Corey, L., Wald, A., Patel, R., Sacks, S. L., Tyring, S. K., Warren, T., Douglas, J. M., Jr., Paavonen, J., Morrow, R. A., Beutner, K. R., Stratchounsky, L. S., Mertz, G., Keene, O. N., Watson, H. A., Tait, D., and Vargas-Cortes, M. (2004). Once-daily valacyclovir to reduce the risk of transmission of genital herpes. $N$ Engl J Med 350(1), 11-20.

Deng, H., Liu, R., Ellmeier, W., Choe, S., Unutmaz, D., Burkhart, M., Di Marzio, P., Marmon, S., Sutton, R. E., Hill, C. M., Davis, C. B., Peiper, S. C., Schall, T. J., Littman, D. R., and Landau, N. R. (1996). Identification of a major co-receptor for primary isolates of HIV-1. Nature 381(6584), 661-6.

Denton, P. W., Estes, J. D., Sun, Z., Othieno, F. A., Wei, B. L., Wege, A. K., Powell, D. A., Payne, D., Haase, A. T., and Garcia, J. V. (2008). Antiretroviral pre-exposure prophylaxis prevents vaginal transmission of HIV-1 in humanized BLT mice. PLoS Med 5(1), e16. 
Dunn, C. S., Mehtali, M., Houdebine, L. M., Gut, J. P., Kirn, A., and Aubertin, A. M. (1995). Human immunodeficiency virus type 1 infection of human CD4-transgenic rabbits. J Gen Virol 76 ( Pt 6), 1327-36.

Elwood, R. L., Rajnik, M., Wilson, S., Yim, K., Blanco, J. C., Nikonenko, B., and Hemming, V. G. (2009). Characterization of late tuberculosis infection in Sigmodon hispidus. Tuberculosis (Edinb) 89(2), 183-8.

Elwood, R. L., Wilson, S., Blanco, J. C., Yim, K., Pletneva, L., Nikonenko, B., Samala, R., Joshi, S., Hemming, V. G., and Trucksis, M. (2007). The American cotton rat: a novel model for pulmonary tuberculosis. Tuberculosis (Edinb) 87(2), 145-54.

Filice, G., Cereda, P. M., and Varnier, O. E. (1988). Infection of rabbits with human immunodeficiency virus. Nature 335(6188), 366-9.

Freeman, E. E., Weiss, H. A., Glynn, J. R., Cross, P. L., Whitworth, J. A., and Hayes, R. J. (2006). Herpes simplex virus 2 infection increases HIV acquisition in men and women: systematic review and meta-analysis of longitudinal studies. Aids 20(1), 7383.

Fulhorst, C. F., Bowen, M. D., Salas, R. A., Duno, G., Utrera, A., Ksiazek, T. G., De Manzione, N. M., De Miller, E., Vasquez, C., Peters, C. J., and Tesh, R. B. (1999). Natural rodent host associations of Guanarito and pirital viruses (Family Arenaviridae) in central Venezuela. Am J Trop Med Hyg 61(2), 325-30.

Fulhorst, C. F., Monroe, M. C., Salas, R. A., Duno, G., Utrera, A., Ksiazek, T. G., Nichol, S. T., de Manzione, N. M., Tovar, D., and Tesh, R. B. (1997). Isolation, characterization and geographic distribution of Caño Delgadito virus, a newly discovered South American hantavirus (family Bunyaviridae). Virus Res 51(2), 159-71.

Garber, M. E., Wei, P., KewalRamani, V. N., Mayall, T. P., Herrmann, C. H., Rice, A. P., Littman, D. R., and Jones, K. A. (1998). The interaction between HIV-1 Tat and human cyclin $\mathrm{T} 1$ requires zinc and a critical cysteine residue that is not conserved in the murine CycT1 protein. Genes Dev 12(22), 3512-27.

Ginsberg, H. S., Lundholm-Beauchamp, U., Horswood, R. L., Pernis, B., Wold, W. S., Chanock, R. M., and Prince, G. A. (1989). Role of early region 3 (E3) in pathogenesis of adenovirus disease. Proc Natl Acad Sci U S A 86(10), 3823-7.

Ginsberg, H. S., Moldawer, L. L., and Prince, G. A. (1999). Role of the type 5 adenovirus gene encoding the early region $1 \mathrm{~B} 55-\mathrm{kDa}$ protein in pulmonary pathogenesis. Proc Natl Acad Sci U S A 96(18), 10409-11.

Glass, G. E., Livingstone, W., Mills, J. N., Hlady, W. G., Fine, J. B., Biggler, W., Coke, T., Frazier, D., Atherley, S., Rollin, P. E., Ksiazek, T. G., Peters, C. J., and Childs, J. E. (1998). Black Creek Canal Virus infection in Sigmodon hispidus in southern Florida. Am J Trop Med Hyg 59(5), 699-703.

Hutchinson, K. L., Rollin, P. E., and Peters, C. J. (1998). Pathogenesis of a North American hantavirus, Black Creek Canal virus, in experimentally infected Sigmodon hispidus. Am J Trop Med Hyg 59(1), 58-65.

Keppler, O. T., Welte, F. J., Ngo, T. A., Chin, P. S., Patton, K. S., Tsou, C. L., Abbey, N. W., Sharkey, M. E., Grant, R. M., You, Y., Scarborough, J. D., Ellmeier, W., Littman, D. R., Stevenson, M., Charo, I. F., Herndier, B. G., Speck, R. F., and Goldsmith, M. A. (2002). Progress toward a human CD4/CCR5 transgenic rat model for de novo infection by human immunodeficiency virus type 1. J Exp Med 195(6), 719-36. 
Keppler, O. T., Yonemoto, W., Welte, F. J., Patton, K. S., Iacovides, D., Atchison, R. E., Ngo, T., Hirschberg, D. L., Speck, R. F., and Goldsmith, M. A. (2001). Susceptibility of ratderived cells to replication by human immunodeficiency virus type 1. J Virol 75(17), 8063-73.

Langley, R. J., Prince, G. A., and Ginsberg, H. S. (1998). HIV type-1 infection of the cotton rat (Sigmodon fulviventer and S. hispidus). Proc Natl Acad Sci U S A 95(24), 14355-60.

Lewandowski, G., Zimmerman, M. N., Denk, L. L., Porter, D. D., and Prince, G. A. (2002). Herpes simplex type 1 infects and establishes latency in the brain and trigeminal ganglia during primary infection of the lip in cotton rats and mice. Arch Virol 147(1), 167-79.

Li, X., Sambhara, S., Li, C. X., Ettorre, L., Switzer, I., Cates, G., James, O., Parrington, M., Oomen, R., Du, R. P., and Klein, M. (2000). Plasmid DNA encoding the respiratory syncytial virus $G$ protein is a promising vaccine candidate. Virology 269(1), 54-65.

Malley, R., DeVincenzo, J., Ramilo, O., Dennehy, P. H., Meissner, H. C., Gruber, W. C., Sanchez, P. J., Jafri, H., Balsley, J., Carlin, D., Buckingham, S., Vernacchio, L., and Ambrosino, D. M. (1998). Reduction of respiratory syncytial virus (RSV) in tracheal aspirates in intubated infants by use of humanized monoclonal antibody to RSV F protein. J Infect Dis 178(6), 1555-61.

Mantooth, S. J., Milazzo, M. L., Bradley, R. D., Hice, C. L., Ceballos, G., Tesh, R. B., and Fulhorst, C. F. (2001). Geographical distribution of rodent-associated hantaviruses in Texas. J Vector Ecol 26(1), 7-14.

Mariani, R., Rasala, B. A., Rutter, G., Wiegers, K., Brandt, S. M., Krausslich, H. G., and Landau, N. R. (2001). Mouse-human heterokaryons support efficient human immunodeficiency virus type 1 assembly. J Virol 75(7), 3141-51.

Mark, K. E., Wald, A., Magaret, A. S., Selke, S., Olin, L., Huang, M. L., and Corey, L. (2008). Rapidly cleared episodes of herpes simplex virus reactivation in immunocompetent adults. J Infect Dis 198(8), 1141-9.

Melkus, M. W., Estes, J. D., Padgett-Thomas, A., Gatlin, J., Denton, P. W., Othieno, F. A., Wege, A. K., Haase, A. T., and Garcia, J. V. (2006). Humanized mice mount specific adaptive and innate immune responses to EBV and TSST-1. Nat Med 12(11), 131622.

Nagot, N., Ouedraogo, A., Foulongne, V., Konate, I., Weiss, H. A., Vergne, L., Defer, M. C., Djagbare, D., Sanon, A., Andonaba, J. B., Becquart, P., Segondy, M., Vallo, R., Sawadogo, A., Van de Perre, P., and Mayaud, P. (2007). Reduction of HIV-1 RNA levels with therapy to suppress herpes simplex virus. N Engl J Med 356(8), 790-9.

Nath, B. M., Schumann, K. E., and Boyer, J. D. (2000). The chimpanzee and other nonhuman-primate models in HIV-1 vaccine research. Trends Microbiol 8(9), 426-31.

Niewiesk, S. (2001). Studying experimental measles virus vaccines in the presence of maternal antibodies in the cotton rat model (Sigmodon hispidus). Vaccine 19(17-19), 2250-3.

Niewiesk, S., Eisenhuth, I., Fooks, A., Clegg, J. C., Schnorr, J. J., Schneider-Schaulies, S., and ter Meulen, V. (1997). Measles virus-induced immune suppression in the cotton rat (Sigmodon hispidus) model depends on viral glycoproteins. J Virol 71(10), 7214-9.

Ottolini, M. G., Porter, D. D., Hemming, V. G., and Prince, G. A. (2000). Enhanced pulmonary pathology in cotton rats upon challenge after immunization with inactivated parainfluenza virus 3 vaccines. Viral Immunol 13(2), 231-6. 
Parr, M. B., Kepple, L., McDermott, M. R., Drew, M. D., Bozzola, J. J., and Parr, E. L. (1994). A mouse model for studies of mucosal immunity to vaginal infection by herpes simplex virus type 2. Lab Invest 70(3), 369-80.

Parr, M. B., and Parr, E. L. (2003). Intravaginal administration of herpes simplex virus type 2 to mice leads to infection of several neural and extraneural sites. J Neurovirol 9(6), 594-602.

Piazza, F. M., Johnson, S. A., Ottolini, M. G., Schmidt, H. J., Darnell, M. E., Hemming, V. G., and Prince, G. A. (1992). Immunotherapy of respiratory syncytial virus infection in cotton rats (Sigmodon fulviventer) using IgG in a small-particle aerosol. J Infect Dis 166(6), 1422-4.

Porter, D. D., Prince, G. A., Hemming, V. G., and Porter, H. G. (1991). Pathogenesis of human parainfluenza virus 3 infection in two species of cotton rats: Sigmodon hispidus develops bronchiolitis, while Sigmodon fulviventer develops interstitial pneumonia. J Virol 65(1), 103-11.

Prince, G. A., Curtis, S. J., Yim, K. C., and Porter, D. D. (2001). Vaccine-enhanced respiratory syncytial virus disease in cotton rats following immunization with Lot 100 or a newly prepared reference vaccine. J Gen Virol 82(Pt 12), 2881-8.

Prince, G. A., Jenson, A. B., Horswood, R. L., Camargo, E., and Chanock, R. M. (1978). The pathogenesis of respiratory syncytial virus infection in cotton rats. Am J Pathol 93(3), 771-91.

Prince, G. A., Prieels, J. P., Slaoui, M., and Porter, D. D. (1999). Pulmonary lesions in primary respiratory syncytial virus infection, reinfection, and vaccine-enhanced disease in the cotton rat (Sigmodon hispidus). Lab Invest 79(11), 1385-92.

Roberts, C. (2005). Genital herpes in young adults: changing sexual behaviours, epidemiology and management. Herpes 12(1), 10-4.

Roberts, C. M., Pfister, J. R., and Spear, S. J. (2003). Increasing proportion of herpes simplex virus type 1 as a cause of genital herpes infection in college students. Sex Transm Dis 30(10), 797-800.

Rodriguez, W. J., Gruber, W. C., Groothuis, J. R., Simoes, E. A., Rosas, A. J., Lepow, M., Kramer, A., and Hemming, V. (1997). Respiratory syncytial virus immune globulin treatment of RSV lower respiratory tract infection in previously healthy children. Pediatrics 100(6), 937-42.

Rojas-Martinez, A., Wyde, P. R., Montgomery, C. A., Chen, S. H., Woo, S. L., and AguilarCordova, E. (1998). Distribution, persistency, toxicity, and lack of replication of an E1A-deficient adenoviral vector after intracardiac delivery in the cotton rat. Cancer Gene Ther 5(6), 365-70.

Rytik, P. G., Il'kevich Iu, G., Poleshchuk, N. N., Miuller, V., Kucherov, I. A., Duboiskaia, G. P., Podol'skaia, I. A., Novikova, I. E., and Kvacheva, Z. B. (1995). [Morphological characteristics of the course of HIV infection in laboratory animals]. Vestn Ross Akad Med Nauk(6), 37-41.

Rytik, P. G., Kutcherov, II, Muller, W. E., Poleschuk, N. N., Duboiskaya, G. P., Kruzo, M., and Podolskaya, I. A. (2004). Small animal model of HIV-1 infection. J Clin Virol 31 Suppl 1, S83-7.

Sadowski, W., Semkow, R., Wilczynski, J., Krus, S., and Kantoch, M. (1987). [The cotton rat (Sigmodon hispidus) as an experimental model for studying viruses in human 
respiratory tract infections. I. Para-influenza virus type 1, 2 and 3, adenovirus type 5 and RS virus]. Med Dosw Mikrobiol 39(1), 33-42.

Sawada, S., Gowrishankar, K., Kitamura, R., Suzuki, M., Suzuki, G., Tahara, S., and Koito, A. (1998). Disturbed CD4+ T cell homeostasis and in vitro HIV-1 susceptibility in transgenic mice expressing T cell line-tropic HIV-1 receptors. J Exp Med 187(9), 1439-49.

Speck, R. F., Penn, M. L., Wimmer, J., Esser, U., Hague, B. F., Kindt, T. J., Atchison, R. E., and Goldsmith, M. A. (1998). Rabbit cells expressing human CD4 and human CCR5 are highly permissive for human immunodeficiency virus type 1 infection. J Virol 72(7), 5728-34.

Stantchev, T. S., and Broder, C. C. (2001). Human immunodeficiency virus type-1 and chemokines: beyond competition for common cellular receptors. Cytokine Growth Factor Rev 12(2-3), 219-43.

Tang, R. S., Nguyen, N., Cheng, X., and Jin, H. (2001). Requirement of cysteines and length of the human respiratory syncytial virus M2-1 protein for protein function and virus viability. J Virol 75(23), 11328-35.

Tervo, H. M., and Keppler, O. T. High natural permissivity of primary rabbit cells for HIV-1, with a virion infectivity defect in macrophages as the final replication barrier. $J$ Virol 84(23), 12300-14.

Tsubota, K., Inoue, H., Ando, K., Ono, M., Yoshino, K., and Saito, I. (1998). Adenovirusmediated gene transfer to the ocular surface epithelium. Exp Eye Res 67(5), 531-8.

van Maanen, M., and Sutton, R. E. (2003). Rodent models for HIV-1 infection and disease. Curr HIV Res 1(1), 121-30.

Wald, A., Zeh, J., Selke, S., Warren, T., Ryncarz, A. J., Ashley, R., Krieger, J. N., and Corey, L. (2000). Reactivation of genital herpes simplex virus type 2 infection in asymptomatic seropositive persons. N Engl J Med 342(12), 844-50.

Wang, E., Bowen, R. A., Medina, G., Powers, A. M., Kang, W., Chandler, L. M., Shope, R. E., and Weaver, S. C. (2001). Virulence and viremia characteristics of 1992 epizootic subtype IC Venezuelan equine encephalitis viruses and closely related enzootic subtype ID strains. Am J Trop Med Hyg 65(1), 64-9.

Watson-Jones, D., Weiss, H. A., Rusizoka, M., Changalucha, J., Baisley, K., Mugeye, K., Tanton, C., Ross, D., Everett, D., Clayton, T., Balira, R., Knight, L., Hambleton, I., Le Goff, J., Belec, L., and Hayes, R. (2008). Effect of herpes simplex suppression on incidence of HIV among women in Tanzania. N Engl J Med 358(15), 1560-71.

Wei, P., Garber, M. E., Fang, S. M., Fischer, W. H., and Jones, K. A. (1998). A novel CDK9associated C-type cyclin interacts directly with HIV-1 Tat and mediates its highaffinity, loop-specific binding to TAR RNA. Cell 92(4), 451-62.

Wildner, O., and Morris, J. C. (2002). Subcutaneous Administration of a ReplicationCompetent Adenovirus Expressing HSV-tk to Cotton Rats: Dissemination, Persistence, Shedding, and Pathogenicity. Hum Gene Ther 13(1), 101-12.

Wyde, P. R., Moore-Poveda, D. K., Daley, N. J., and Oshitani, H. (1999). Replication of clinical measles virus strains in hispid cotton rats. Proc Soc Exp Biol Med 221(1), 5362.

Xu, F., Sternberg, M. R., Kottiri, B. J., McQuillan, G. M., Lee, F. K., Nahmias, A. J., Berman, S. M., and Markowitz, L. E. (2006). Trends in herpes simplex virus type 1 and type 2 seroprevalence in the United States. Jama 296(8), 964-73. 
Yim, K. C., Carroll, C. J., Tuyama, A., Cheshenko, N., Carlucci, M. J., Porter, D. D., Prince, G. A., and Herold, B. C. (2005). The cotton rat provides a novel model to study genital herpes infection and to evaluate preventive strategies. J Virol 79(23), 14632-9. 


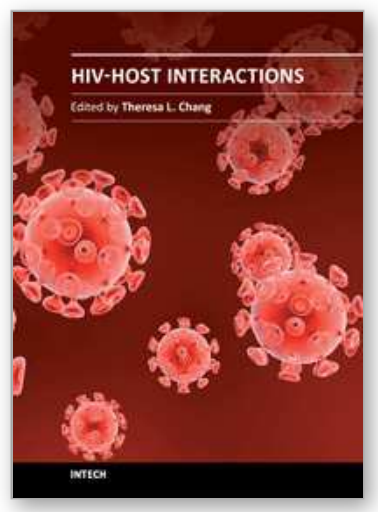

\section{HIV-Host Interactions}

Edited by Dr. Theresa Li-Yun Chang

ISBN 978-953-307-442-9

Hard cover, 364 pages

Publisher InTech

Published online 02, November, 2011

Published in print edition November, 2011

HIV remains the major global health threat, and neither vaccine nor cure is available. Increasing our knowledge on HIV infection will help overcome the challenge of HIV/AIDS. This book covers several aspects of HIV-host interactions in vitro and in vivo. The first section covers the interaction between cellular components and HIV proteins, Integrase, Tat, and Nef. It also discusses the clinical relevance of HIV superinfection. The next two chapters focus on the role of innate immunity including dendritic cells and defensins in HIV infection followed by the section on the impact of host factors on HIV pathogenesis. The section of co-infection includes the impact of Human herpesvirus 6 and Trichomonas vaginalis on HIV infection. The final section focuses on generation of HIV molecular clones that can be used in macaques and the potential use of cotton rats for HIV studies.

\section{How to reference}

In order to correctly reference this scholarly work, feel free to copy and paste the following:

Jorge C.G. Blanco, Lioubov M. Pletneva, Lorraine E. Earle and William I. Frels (2011). The Quest for a Small Animal Model for HIV Infection and Disease, HIV-Host Interactions, Dr. Theresa Li-Yun Chang (Ed.), ISBN: 978-953-307-442-9, InTech, Available from: http://www.intechopen.com/books/hiv-host-interactions/the-questfor-a-small-animal-model-for-hiv-infection-and-disease

\section{INTECH}

open science | open minds

\author{
InTech Europe \\ University Campus STeP Ri \\ Slavka Krautzeka 83/A \\ 51000 Rijeka, Croatia \\ Phone: +385 (51) 770447 \\ Fax: +385 (51) 686166 \\ www.intechopen.com
}

\author{
InTech China \\ Unit 405, Office Block, Hotel Equatorial Shanghai \\ No.65, Yan An Road (West), Shanghai, 200040, China \\ 中国上海市延安西路 65 号上海国际贵都大饭店办公楼 405 单元 \\ Phone: +86-21-62489820 \\ Fax: +86-21-62489821
}


(C) 2011 The Author(s). Licensee IntechOpen. This is an open access article distributed under the terms of the Creative Commons Attribution 3.0 License, which permits unrestricted use, distribution, and reproduction in any medium, provided the original work is properly cited. 